\title{
Platelet indices in dogs with thrombocytopenia and dogs with normal platelet counts
}

\author{
Índices plaquetarios en perros con trombocitopenia y perros con recuentos \\ de plaquetas normales
}

\author{
AM Souza $^{a^{*}}$, JJ Pereira ${ }^{\text {a }}$, SDE Campos ${ }^{\mathrm{a}}$, RA Torres-Filho ${ }^{\mathrm{b}}$, MS Xavier ${ }^{\mathrm{a}}$, \\ DTL Bacellar ${ }^{\mathrm{c}}$, NRP Almosny ${ }^{\mathrm{a}}$
}

\begin{abstract}
It is well known that thrombocytopenia is the most commonly acquired haemostatic disorder in dogs and can be potentially life-threatening. With the use of automated analysers, platelet indices such as Mean Platelet Volume (MPV), Platelet Distribution Width (PDW), and Platelet Large Cell Ratio (P-LCR), became routinely available, allowing data comparison and error checks which results in a more effective quality control. The aim of this study was to evaluate the pattern of platelet indices (MPV, PDW and P-LCR) in dogs with thrombocytopenia and with normal platelet values. The results of $351 \mathrm{CBCs}$ processed in an automated veterinary haematology counter Sysmex ${ }^{\circledR}$ pocH-100iV Diff were analysed. Two groups of dogs were established, those with thrombocytopenia (45) and those with normal platelet counts (306). Thrombocytopenic dogs were subdivided in dogs with less than 150,000 platelets/ $\mu \mathrm{L}$ of blood $(19 / 42,2 \%)$ and dogs with over 150,000 platelets / $\mu \mathrm{L}$ of blood (26/57,8\%). Mean values of PDW and P-LCR indices in thrombocytopenic animals were significantly higher than the mean values of animals with normal platelet counts. There was no significant difference in any of the indices in either group of thrombocytopenic dogs. Macroplatelets were present in the blood smears of thrombocytopenic dogs. Results suggested increased thrombopoiesis and release of different sized platelets. It was concluded that both PDW and P-LCR increase in dogs with thrombocytopenia and they are more sensitive than MPV. P-LCR is also important in thrombocytopenic dogs, especially when associated to the presence of large platelets in blood smears.

Key words: platelets, anisocytosis, blood cell analyzer, platelet distribution width.
\end{abstract}

RESUMEN. Es conocido que la trombocitopenia es el trastorno hemostático más común de los perros y una potencial amenaza de vida. Utilizando analizadores automatizados, los índices plaquetarios como el Volumen Plaquetario Medio (MPV), la Amplitud de Distribución Plaquetaria (PDW) y el Porcentaje de Plaquetas Grandes (P-LCR) han sido exámenes rutineros, permitiendo comparaciones de datos y verificaciones de errores y, consecuentemente, un mayor control de calidad. El objetivo del estudio consistió en evaluar el patrón de los índices plaquetarios (MPV, PDW y P-LCR ) en perros trombocitopénicos y perros con valores plaquetarios normales. Fueron analizados los resultados de 351 hemogramas procesados en un contador automatizado de hematología veterinaria Sysmex ${ }^{\circledR}$ pocH-100iV Diff. Los perros fueron divididos entre los trombocitopénicos (45) y aquellos con recuentos plaquetarios normales (306). Se dividieron los perros trombocitopénicos entre los que presentaban menos que 150.000 plaquetas $/ \mu \mathrm{L}$ de sangre $(19 / 42,2 \%)$ y los que tenían más que 150.000 plaquetas/ $\mu \mathrm{L}$ de sangre (26/57,8\%). Los promedios de los índices de PDW y P-LCR en los trombocitopénicos fueron significativamente mayores que aquellos de animales con recuentos plaquetarios normales. No hubo diferencias significativas en ninguno de los índices entre los grupos trombocitopénicos. Los resultados sugieren un aumento de la trombopoyesis y de la liberación de plaquetas con tamaños diferentes. Se concluyó que el PDW y el P-LCR aumentan en perros trombocitopénicos y son más sensibles que el MPV. El L-PCR también es importante en perros trombocitopénicos, principalmente cuando son asociados a la presencia de plaquetas grandes en el extendido de sangre.

Palabras clave: plaquetas, anisocitosis, contador automatizado de hematología, Amplitud de Distribución Plaquetaria.

\section{INTRODUCTION}

A complete blood count (CBC) is an important tool for assessing animal's clinical status since it provides quantitative and qualitative information on all blood cells (Rizzi et al 2010). Increase in automated blood cell analyzers'

Accepted: 25.02.2016.

${ }^{a}$ Departamento de Patologia e Clínica Veterinária, Faculdade de Veterinária, Universidade Federal Fluminense, Niterói, Brazil.

bepartamento de Zootecnia, Faculdade de Veterinária, Universidade Federal Fluminense, Niterói, Brazil.

'Instituto Nacional de Controle de Qualidade em Saúde, FIOCRUZ, Rio de Janeiro, Brasil.

*Corresponding author: AM Souza; Rua Vital Brazil Filho 64, Vital Brazil, Niterói, RJ 21230-360, Brazil; alinems@id.uff.br availability has provided indices that were not previously calculated in manually performed CBCs, such as Red Blood Cell Distribution Width (RDW), which has led to new approaches in anemic patients (Balarin et al 2001, Žvorc et al 2010, Temizel et al 2011, Souza et al 2012).

Platelet quantification in peripheral blood is a well-recognised tool in veterinary diagnostics. Thrombocytopenia is the most commonly acquired hemostatic disorder in dogs and can become potentially life-threatening (Grindem et al 1991, Bommer et al 2008). Severe thrombocytopenia in dogs is mostly caused by immune-mediated thrombocytopenia; however, low platelet counts are also commonly associated with inflammatory, infectious or neoplastic diseases (Bommer et al 2008, Botsch et al 2009).

Recently, new erythrocyte and platelet count related indices have been provided by hematologic analyzers. 
However, despite practical applications of red blood cell (RBC) indices in dogs, platelet indices are not yet currently used in daily clinical practices to evaluate thrombocytopenia (Temizel et al 2011). Reduced platelet production and acceleration of platelet destruction, consumption and/or sequestration are the major mechanisms of thrombocytopenia in a variety of diseases in dogs (Bommer et al 2008).

Along with reticulocyte counts, Mean Corpuscular Volume (MCV) is the most widely used parameter for anemia classification and bone marrow response evaluation (Weiss and Townsend 1998, Neiger et al 2002, Žvorc et al 2010). Regardless of reticulocyte counts and bone marrow cytological examinations, regeneration can be evaluated by using RBC and platelet indices (Flaiban and Balarin 2004).

Souza et al (2012) demonstrated RBC indices provide important information on anemia in dogs, therefore, platelet indices can provide clinical information on thrombocytopenia's underlying conditions. Platelet volume indices, such as Mean Platelet Volume (MPV), which represents average platelet size, and Platelet Distribution Width (PDW), which represents platelet size heterogeneity, are now routinely available.

MPV can be used to assess response of patients with thrombocytopenia. Considering the larger size of early released platelets, an increased MPV could indicate active thrombopoiesis (Northern and Tvedten 1992). Human immune-mediated thrombocytopenia characteristically presents an increased MPV, reflecting the release of large immature platelets from hyperplastic megakaryocytes in response to peripheral thrombocytopenia (Diquattro et al 2009, Noris et al 2009). Moreover, thrombocytopenia associated with a decreased MPV suggests insufficient megakaryocytes or bone marrow failure (Topper and Welles 2003). Besides its use in thrombocytopenia, increased MPV was reported as an indicator of sepsis in dogs (Moritz et al 2005).

Two other indices (Platelet Distribution Width = PDW; and Platelet Large Cell Ratio $=$ P-LCR) complement MPV interpretations in platelet evaluations. An increased platelet size increases PDW levels just as an increased erythrocyte size increases RDW levels (Schwartz et al 2014). To our advantage, PDW can rise due to small variations in platelet morphology before MPV values are altered, similar to what occurs with the anisocytosis index, RDW, showing the greater sensitivity of PDW (Matos et al 2008). As for P-LCR, this index indicates the percentage of large sized platelets in the blood stream (Silveira et al 2003).

Association of differential blood counts with automated analyser results enables data comparison and error checks, resulting in a more effective quality control. In addition, automated methods provide previously unreached parameters in manually performed methodologies.

The aim of this study was to evaluate pattern of platelet indices (MPV, PDW and P-LCR) in thrombocytopenic dogs and dogs with normal platelet values.

\section{MATERIAL AND METHODS}

This study was approved by Ethics Committee on Animal Research of Universidade Federal Fluminense (CEUA-UFF), under the number 00157/09.

Results of 351 CBCs performed at Laboratório de Pesquisa Clínica e Molecular Marcilio Dias do Nascimento of Universidade Federal Fluminense (LAMADIN-UFF) and processed in an automated veterinary hematology counter Sysmex ${ }^{\circledR}$ pocH-100iV Diff (Sysmex do Brasil Indústria e Comércio Ltda®, São José dos Pinhais, Paraná, Brasil) were analysed from September 2009 to March 2011.

Results were initially divided into thrombocytopenic dogs (platelet count $<200,000 / \mu \mathrm{L}$ ) and dogs with platelet counts within normal range $(200,000 \leq x \leq 700,000 / \mu \mathrm{L})$. In order to avoid repetition of animals in this study, in case the same animal possessed more than one blood count, only blood test results from the first clinical evaluation of these animals were used.

Thrombocytopenic dogs were then subdivided into two groups according to their platelet count where the first group of dogs had less than 150,000 platelets $/ \mu \mathrm{L}$ of blood and the second group over 150,000 platelets $/ \mu \mathrm{L}$ of blood. Means and standard deviations of platelet indices (PDW, MPV and P-LCR ) were determined for each group. Blood smears were stained by Diff Quick (Panótico Instant Prov $($ ) and analyzed at 1,000x magnification to confirm analyser's results and search for abnormalities. Blood smear morphological evaluations were performed in the area located immediately prior to feathered edge, where there is no overlapping of red blood cells.

\section{STATISTICAL ANALYSIS}

It was conducted chi-square test to assess treatments' effect on frequency's dispersion of responses with a 5\% significance. Descriptive statistics was performed in order to evaluate results and expressed as Mean \pm Standard Deviation (DE) in tables 1 and 2.

\section{RESULTS}

Blood count analyses showed 45 dogs (12.82\%) with thrombocytopenia (platelet count $<200,000 / \mu \mathrm{L}$ ) and 306 dogs $(87.18 \%)$ with an adequate platelet count $(200.000 \leq$ $\mathrm{x} \leq 700.000 / \mu \mathrm{L})$. Thrombocytopenic animals $(\mathrm{n}=45)$ were divided into two groups: the first with 19 dogs (42.2\%) and the second with $26(57.8 \%)$. Mean values and standard deviations of platelet indices (MPV, PDW and P-LCR) in thrombocytopenic and non-thrombocytopenic dogs processed in Sysmex ${ }^{\circledR}$ pocH-100iV Diff are shown in table 1. Mean values and standard deviations of platelet indices for each group of thrombocytopenic dogs are shown in table 2.

There were no significant differences in MPV values between thrombocytopenic dogs and dogs with platelet counts within normal range. However, there were significant 
Table 1. Mean values and standard deviations (SD) of platelet indices (MPV, PDW and P-LCR) from blood samples of thrombocytopenic and non-thrombocytopenic dogs processed in Sysmex ${ }^{\circledR}$ pocH-100iV Diff hematology analyser. Laboratório de Pesquisa Clínica e Molecular Marcilio Dias do Nascimento, 2011.

Promedios y desviaciones estándares (DE) de índices plaquetarios (MPV, PDW y P-LCR) de muestras sanguíneas de perros trombocitopénicos y no trombocitopénicos procesados en un analizador de hematología Sysmex ${ }^{\circledR}$ pocH-100iV Diff. Laboratório de Pesquisa Clínica e Molecular Marcilio Dias do Nascimento, 2011.

\begin{tabular}{lcc}
\hline \multirow{2}{*}{ Variable } & $\begin{array}{c}\text { Thrombocytopenic } \\
(\mathrm{N}=44)\end{array}$ & $\begin{array}{c}\text { Non-thrombocytopenic } \\
(\mathrm{N}=307)\end{array}$ \\
\cline { 2 - 3 } & Mean* $\pm \mathrm{SD}$ & Mean* $^{*} \mathrm{SD}$ \\
\hline PDW $(\%)^{1}$ & $14.685^{\mathrm{A}} \pm 2.527$ & $12.858^{\mathrm{B}} \pm 2.195$ \\
MPV (fL) & $11.725^{\mathrm{A}} \pm 1.153$ & $11.941^{\mathrm{A}} \pm 4.422$ \\
P-LCR $(\%)^{3}$ & $41.879^{\mathrm{A}} \pm 14.061$ & $35.400^{\mathrm{B}} \pm 13.031$ \\
\hline
\end{tabular}

1 Platelet Distribution Width; ${ }^{2}$ Mean Platelet Volume; ${ }^{3}$ Platelet Large Cell Ratio

* Means followed by the same letter did not differ at a 5\% significance by the Chi-square.

Table 2. Mean values and standard deviations (SD) of platelet indices (MPV, PDW and P-LCR) from blood samples of thrombocytopenic dogs processed in Sysmex ${ }^{\circledR}$ pocH-100iV Diff hematology analyser. Laboratório de Pesquisa Clínica e Molecular Marcilio Dias do Nascimento, 2011.

Promedios y desviaciones estándares (DE) de índices plaquetarios (MPV, PDW y P-LCR) de muestras sanguíneas de perros trombocitopénicos procesados en un analizador de hematología Sysmex ${ }^{\circledR}$ pocH-100iV Diff. Laboratório de Pesquisa Clínica e Molecular Marcilio Dias do Nascimento, 2011.

\begin{tabular}{lcc}
\hline \multirow{2}{*}{ Variable } & \multicolumn{2}{c}{ Thrombocytopenic } \\
\cline { 2 - 3 } & $1^{\text {st }}$ group & $2^{\text {nd }}$ group \\
\cline { 2 - 3 } & Mean* \pm SD & Mean* \pm SD $^{*}$ \\
\hline PDW (\%) & $15.09^{\mathrm{A}} \pm 2.76$ & $14.45^{\mathrm{A}} \pm 2.21$ \\
MPV (fL) & $11.76^{\mathrm{A}} \pm 1.25$ & $11.73^{\mathrm{A}} \pm 1.94$ \\
P-LCR $(\%)^{3}$ & $40.18^{\mathrm{A}} \pm 13.73$ & $44.03^{\mathrm{A}} \pm 13.58$ \\
\hline
\end{tabular}

1 Platelet Distribution Width; ${ }^{2}$ Mean Platelet Volume; ${ }^{3}$ Platelet Large Cell Ratio.

* Means followed by the same letter did not differ at a 5\% significance by the Chi-square.

differences in PDW and P-LCR indices where mean values of animals with thrombocytopenia were significantly higher than mean values of animals with normal platelet counts.

Chi-square between results of thrombocytopenic groups showed no significant difference in any of the tested indices.

Blood smear analysis of thrombocytopenic dogs showed platelet anisocytosis and macroplatelets in 6 animals (13.33\%), 3 of which were from the first group and 3 from the second group. There were no platelet aggregates in either group.

Clinical data of thrombocytopenic animals $(n=45)$ showed $31.11 \%$ of the dogs were cancer patients, $24.44 \%$ had a tick infestation and suspected hemoparasitosis, $11.11 \%$ only showed prostration and loss of appetite with no conclusive diagnosis, $6.67 \%$ had a respiratory disease, $4.44 \%$ had renal failure and $22.22 \%$ consisted of dogs with other clinical findings. Microfilariae were found in blood smears of 2 thrombocytopenic dogs.

\section{DISCUSSION}

Increased PDW and P-LCR levels suggest increased thrombopoiesis and release of different sized platelets which was only microscopically evidenced by presence of macroplatelets and platelet anisocytosis in blood smear of $13.33 \%$ dogs with thrombocytopenia. Reinforcing this hypothesis, certain studies have already described how humans and dogs could respond to thrombocytopenia by increasing megakaryocyte numbers or by producing larger and more biologically active platelets (Minter and Ingram 1971, Martin et al 1983).

Schwartz et al (2014) suggested that presumptive primary immune-mediated thrombocytopenia in dogs is characterized by increased MPV levels due to large immature platelets` production during a regenerative process. However, this was not observed in our study. Similar to this, other studies have observed that a decreased MPV may be associated with early stages of immune-mediated thrombocytopenia and it is believed that this reduction could be caused by presence of small platelets (Northern and Tvedten 1992, Topper and Welles 2003). Another study reported that $0 / 13$ dogs suspected with primary immune-mediated thrombocytopenia had increased MPV levels (Dircks et al 2009).

These MPV results may suggest a low sensitivity of this index to platelet heterogeneity similar to what occurs in MCV for red blood cells, which requires a large number of erythrocytes with different volumes for this index to increase (Souza et al 2012). However, in this study, it is possible that there were no differences in thrombocytopenic animals`MPV values due to higher number of dogs with platelet counts between $150,000 / \mu \mathrm{L}$ and $200,000 / \mu \mathrm{L}$, therefore, requiring greater number of dogs with severe thrombocytopenia to significantly raise MPV values. As a result of increased amount of larger platelets during a bone marrow response to thrombocytopenia, an increase in platelet heterogeneity may be observed and, thus, PDW should also increase (Bommer et al 2008) which is what occurred in the present study. Bommer et al (2008) also concluded that PDW is more sensitive to increased amount of large platelets than MPV, partly because MPV values can be influenced by the simultaneous presence of smaller platelets and cell debris.

According to other studies, a high MPV may be a risk marker for activated platelets (Park et al 2002). During an investigation on behavior of MPV in canine babesiosis, investigators found that the average size of platelets in infected dogs was above normal (Kettner et al 2003). 
However, in another study on canine babesiosis, thrombocytopenia was detected in $99.5 \%$ of infected animals, but only $15.3 \%$ showed increased MPV (Zygner et al 2007). This is similar to what occurred in the present study where thrombocytopenic and non-thrombocytopenic dogs presented similar MPV values.

There was no significant difference between the dogs of thrombocytopenic groups in any tested indices. This suggests the degree of thrombocytopenia can not interfere with behavior of these indices. However, it is possible that low number of animals in each group contributed to development of this profile.

Thrombocytopenic animals showed macroplatelets and platelet anisocytosis in morphological analyses. Large platelets can be observed in peripheral blood when bone marrow is intact and when it is overstimulated to produce platelets (Kaito et al 2005, Bommer et al 2008). Platelet aggregation was not observed in any of the thrombocytopenia cases, discarding pseudothrombocytopenia by platelet agglutination hypothesis. Tick infestation and cancer were the main clinical data reported in animals with thrombocytopenia. Low platelet counts are believed to be commonly associated with inflammatory, infectious or neoplastic diseases (Bommer et al 2008, Botsch et al 2009) which are in accordance with results of our study. Smith et al (2014) observed that PDW increased in dogs with hemangiosarcoma compared to control dogs. Carcinoma, lymphoma and hemangiosarcoma were the most commonly reported cancer in thrombocytopenic animals.

P-LCR distribution patterns were in agreement with findings of Babu and Basu (2004) who detected significantly increased P-LCR values in human patients with thrombocytopenia. These authors concluded that P-LCR was inversely related to platelet counts and directly related to PDW and MPV, as occurred in our study, with P-LCR, PDW and platelet count results, but not MPV values.

Various studies have stated that platelet indices, especially MPV and PDW, can provide clinical information on the mechanisms of thrombocytopenia (Bowles et al 2005, Kaito et al 2005). However, in the present study, we alert the importance of P-LCR index in thrombocytopenic dogs, especially when associated to presence of large platelets in blood smears.

It was concluded that PDW and P-LCR are more sensitive to changes in platelet volume than MPV since PDW and P-LCR demonstrated a significant increase in dogs with thrombocytopenia and, in this study, MPV did not differ between animals with thrombocytopenia and animals with normal platelet counts. Moreover, it was concluded that P-LCR is important when associated to the presence of large platelets in blood smears, indicating an active thrombopoiesis.

\section{ACKNOWLEDGEMENTS}

The authors would like to thank CNPq, FAPERJ and Proppi/UFF for their financial support and scholarship, and Controllab® for quality control.

\section{REFERENCES}

Babu E, D Basu. 2004. Platelet large cell ratio in the differential diagnosis of abnormal platelet counts. Indian J Pathol Microbiol 47, 202-205.

Balarin MRS, JH Fonteque, C Souza, ME Saito, A Kohayagawa, RS Lopes. 2001. Valores da amplitude de distribuição do tamanho dos eritrócitos (RDW - Red Cell Distribuition Width) em equinos da raça Puro Sangue Inglês (PSI) de ambos os sexos de 12 a 24 meses de idade. Semina: Ci Agrárias 22, 135-137.

Bommer NX, DJ Shaw, EM Milne, AE Ridyard. 2008. Platelet distribution width and mean platelet volume in the interpretation of thrombocytopenia in dogs. J Small Anim Pract 49, 518-524.

Botsch V, H Küchenhoff, K Hartmann, J Hirschberger. 2009. Retrospective study of 871 dogs with thrombocytopenia. Vet Rec 164, 647-651.

Bowles KM, LJ Cooke, EM Richards, TP Baglin. 2005. Platelet size has diagnostic predictive value in patients with thrombocytopenia. Clin Lab Haematol 27, 370-373.

DiQuattro M, F Gagliano, GM Calabro, M Tommasi, CS Scott, G Mancuso, B Palma, I Menozzi. 2009. Relationships between platelet counts, platelet volumes and reticulated platelets in patients with ITP: Evidence for significant platelet count inaccuracies with conventional instrument methods. Int J Hematol 31, 199-206.

Dircks BH, HJ Schuberth, R Mischke. 2009. Underlying diseases and clinicopathologic variables of thrombocytopenic dogs with and without platelet-bound antibodies detected by use of a flow cytometric assay: 83 cases (2004-2006). J Am Vet Med Assoc 235, 960-966.

Flaiban KKMC, MRS Balarin. 2004. Estudo comparativo entre a amplitude de variação dos eritrócitos (RDW-Red Blood Cell Distribution Width) e o Volume Globular (VG), Volume Globular Médio (VGM) e a presença de anisocitose em extensão sangüínea em cães. Semina: Ci. Agrárias 25, 125-130.

Grindem CB, EB Breitschwerdt, WT Corbett, HE Jans. 1991. Epidemiologic survey of thrombocytopenia in dogs: a report on 987 cases. Vet Clin Pathol 20, 8-43.

Kaito K, H Otsubo, N Usui, M Yoshida, J Tanno, E Kurihara, K Matsumoto, R Hirata, K Domitsu, M Kobayashi. 2005. Platelet size deviation width, platelet large cell ratio, and mean platelet volume have sufficient sensitivity and specificity in the diagnosis of immune thrombocytopenia. Brit J Haematol 128, 698-702.

Kettner FF, D Reyers, D Miller. 2003. Thrombocytopenia in canine babesiosis and its clinical usefulness. J S Afr Vet Assoc 74, 63-68.

Martin JF, EA Trowbridge, G Salmon, J Plumb. 1983. The biological significance of platelet volume. Its relationship to bleeding time, platelet thromboxane B2 production and megakaryocyte nuclear DNA concentration. Thromb Res 32, 443-460.

Matos JF, MG Carvalho, LMS Dusse, MFR Ferreira, RVB Stubbert. 2008. O papel do RDW, da morfologia eritrocitária e de parâmetros plaquetários na diferenciação entre anemias microcíticas e hipocrômicas. Rev Bras Hematol Hemoter 30, 463-469.

Minter FM, M Ingram. 1971. Platelet volume: density relationships in normal and acutely bled dogs. Brit J Haematol 20, 55-68.

Moritz A, BK Walcheck, DJ Weiss. 2005. Evaluation of flow cytometric and automated methods for detection of activated platelets in dogs with inflammatory disease. Am J Vet Res 66, 325-329.

Neiger R, J Hadley, DU Pfeiffer. 2002. Differentiation of dogs with regenerative and non-regenerative anemia on the basis of their red cell distribution width and mean corpuscular volume. Vet Rec 6, 431-434.

Noris P, C Klersy, M Zecca, L Arcaini, A Pecci, F Melazzini, V Terulla, V Bozzi, C Ambaglio, F Passamonti, F Locatelli, CL Balduini. 2009. Platelet size distinguishes between inherited macrothrombocytopenias and immune thrombocytopenia. J Thromb Haemost 7, 2131-2136.

Northern J, HW Tvedten. 1992. Diagnosis of microthrombocytosis and immune-mediated thrombocytopenia in dogs with thrombocytopenia: 68 cases (1987-1989). J Am Vet Med Assoc 200, 368-372.

Park Y, N Schoene, W Harris. 2002. Mean platelet volume as an indicator of platelet activation: methodological issues. Platelets 13, 301-306. 
Rizzi TE, JH Meinkoth, KD Clinkenbeard. 2010. Normal hematology of the dog. In: Weiss DJ, Wardrop KJ (eds). Schalm's Veterinary Hematology. $6^{\text {th }}$ ed. Wiley-Blackwell, Iowa, USA, Pp 799-810.

Schwartz D, L Sharkey, PJ Armstrong, C Knudson, J Kelley. 2014. Platelet volume and plateletcrit in dogs with presumed primary immune-mediated thrombocytopenia. J Vet Intern Med 28, 1575-1579.

Silveira MM, LM Fonseca, D Guaglianoni. 2003. Série plaquetária: valores de referência e correlações observadas entre os parâmetros plaquetários em uma população aparentemente saudável. Rev Ciênc Farm 24, 107-114.

Smith JR, KF Smith, BM Brainard. 2014. Platelet parameters from an automated hematology analyzer in dogs with inflammatory clinical diseases. Vet J 201, 406-411.

Souza AM, MB Camargo, DTL Bacellar, SDE Campos, RA Torres Filho, NX Alencar, MS Xavier, DB Macieira, NRP Almosny. 2012. Age and sex influence in canine Red Cell Distribution Width (RDW-CV and RDW-SD) values. Rev Bras Ci Vet 19, 90-93.

Temizel EM, H Cihan, Z Yilmaz, N Aytuğ. 2011. Evaluation of erythrocyte and platelet indices in canine visceral leishmaniasis. Ankara Üniv. Ankara Üniv Vet Fak Derg 58, 185-188.

Topper MJ, EG Welles. 2003. Hemostasis In: Latimer KS, Mahaffey EA, Prasse KW (eds). Duncan \& Prasse's Veterinary Laboratory Medicine: clinical pathology. $4^{\text {th }}$ ed. Wiley-Blackwell, Ames, USA, Pp 99-135.

Weiss DJ, E Townsend. 1998. Evaluation of reticulated platelets in dogs. Comp Haematol Int 8, 166-170.

Žvorc Z, R Barić Rafaj, J Kuleš, V Mrljak. 2010. Erythrocyte and platelet indices in babesiosis of dogs. Vet Arhiv 80, 259-267.

Zygner W, O Gójska, G Rapacka, D Jaros, H Wedrychowicz. 2007. Hematological changes during the course of canine babesiosis caused by large Babesia in domestic dogs in Warsaw (Poland). Vet Parasitol 145, 146-151. 
